Check for updates

Cite this: RSC Adv., 2018, 8, 30055

\title{
Nopinone-based aggregation-induced emission (AIE)-active difluoroboron $\beta$-diketonate complex: photophysical, electrochemical and electroluminescence properties $\uparrow$
}

\begin{abstract}
Qian Jiang, ${ }^{a}$ Mingguang Zhang, ${ }^{a}$ Zhonglong Wang, ${ }^{\text {a Jie Song, }}$, Yiqin Yang, ${ }^{\text {ac }}$ Wenchao Li, ${ }^{d}$ Wen Gu, ${ }^{\text {ac }}$ Xu Xu, ${ }^{* a c}$ Haijun Xu*ac and Shifa Wang (iD *ac

Four difluoroboron $\left(\mathrm{BF}_{2}\right) \beta$-diketonate nopinone complexes $3 a-3 d$ that exhibited typical aggregationinduced emission (AIE) properties were synthesized using the natural renewable $\beta$-pinene derivative nopinone as the starting material. The thermal, photophysical, electrochemical and electroluminescent properties as well as the AIE properties of complexes $3 a-3 d$ were analyzed systematically. The data of photophysical and electrochemical demonstrated that compound $3 \mathrm{~b}$ with a methoxy group exhibited the largest bathochromic shift, the highest absolute photoluminescence quantum yields and narrowest optical bandgap among $3 a-3 d$. Using $3 b$ as the emitter, electroluminescent (EL) device I exhibits bluegreen light with CIE coordinates of $(0.2774,0.4531)$ and showed a better performance with a luminous efficacy $\left(\eta_{\mathrm{p}}\right)$ of $7.09 \mathrm{Im} \mathrm{W}^{-1}$ and correlated color temperature $\left(T_{C}\right)$ of $7028 \mathrm{~K}$. The results demonstrate that new AIE compounds are promising solid-state luminescent materials with practical utility in electroluminescent materials.
\end{abstract}

Received 12th June 2018

Accepted 14th August 2018

DOI: $10.1039 / \mathrm{c} 8 \mathrm{ra05031 \textrm {g }}$

rsc.li/rsc-advances performance of traditional luminophores when used in optoelectronic devices. In 2001, Tang discovered the phenomenon of aggregation-induced emission (AIE): luminophores show nonfluorescent in solutions, but highly emissive in aggregate formation or in crystalline state..$^{25}$ The main cause of the AIE effects is restriction of intramolecular motions (RIM), including rotation and vibration along the $\mathrm{C}-\mathrm{C}$ single bond. ${ }^{26}$ Many fluorescent organic dyes showing AIE properties are studied, they include tetraphenylethene, ${ }^{27,28}$ siloles, ${ }^{29-31}$ BODIPY dyes, ${ }^{32,33}$ triphenylethene, ${ }^{34,35}$ tetraphenyl-1,4-butadiene (TPBD), ${ }^{36}$ pentacenequinone ${ }^{37}$ and isophorone ${ }^{38}$ based dyes. Recently, the exploration of new AIE fluorophores is still a challenging field to synthetic chemist. In this paper, a simple strategy to synthesize high-performance solid-state light emitters with AIE property is proposed.

As a rich and cheap plant essential oils, the annual output of turpentine is about 100000 tons or more. Nopinone is a derivative synthesized from $\beta$-pinene, which is a main ingredient of turpentine. In recent years, many nopinone derivatives have been synthesized such as 3-cyanopyridine derivatives, ${ }^{39}$ chiral 1,3-aminoalcohols and 1,3-diols, ${ }^{\mathbf{4 0}}$ terpenyl diselenides, ${ }^{\mathbf{4 1}}$ quinazolin-2-amine nopinone derivatives. ${ }^{42}$ However, there is no work about using the pinane frame to construct some new EL materials.

In this paper, we designed and synthesized four novel nopinone derivatives-containing difluoroboron $\beta$-diketonate groups. The synthetic route is illustrated in Scheme 1. The structures of these compounds are characterized with ${ }^{1} \mathrm{H}$ NMR, 


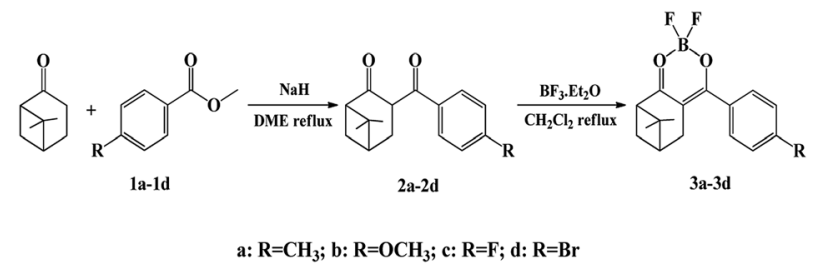

Scheme 1 Synthetic route of compounds $3 a-3 d$.

${ }^{13} \mathrm{C}$ NMR, HRMS and X-ray analyses. The thermal, photophysical, electrochemical properties, and molecular orbital distribution of four new fluorescent compounds are also investigated. Finally, two of them have been successfully applied to electroluminescent devices. This is the first report of nopinone-based fluorescent compounds for electroluminescence materials application.

\section{Experimental}

\subsection{Materials and measurements}

Reagents and solvents were purchased from commercial suppliers and used without further purification. Mass spectra were carried out on an America Agilent 5975c mass spectrometer. The ${ }^{1} \mathrm{H}$ NMR and ${ }^{13} \mathrm{C}$ NMR spectra were recorded in $\mathrm{CDCl}_{3}$ solutions on a Bruker AV 400 spectrometer. Melting points were performed with an X-6 microscopic melting point apparatus. UV-visible absorption spectra were investigated by PerkinElmer Lambda 950. PL emission spectra were investigated by PerkinElmer LS55 fluorescence spectrophotometer scan from

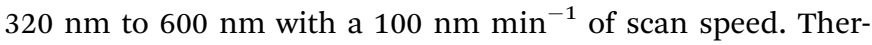
mogravimetric analysis (TGA) was carried out on a TGA 2050 thermogravimetric analyzer under nitrogen at a heating rate of $10{ }^{\circ} \mathrm{C} \min ^{-1}$, and $T_{\mathrm{d}}$ was reported as the temperatures at $5 \%$ weight losses. Cyclic voltammetry was taken on a CHI-600E electrochemical analyzer. The measurements were determined using a conventional three-electrode configuration consisting of a glassy carbon working electrode, a platinum wire auxiliary electrode and an $\mathrm{Ag} / \mathrm{AgCl}$ reference electrode, the scan rate was $10 \mathrm{mV} \mathrm{s}^{-1}$. Fluorescence lifetimes were taken on a steady and transient state fluorometer (Quantaurus-Tau, C11367). The absolute photoluminescence quantum yield $\left(\Phi_{\mathrm{PL}}\right)$ was measured with a Hamamatsu absolute PL quantum yield spectrometer equipped (Quantaurus-QY, C11347). X-ray data were collected on a Bruker D8 Venture area diffractometer.

\subsection{Fabrication of electroluminescent (EL) devices and testing}

Devices was fabricated by embedding the luminophores and curing agent in a transparent silicone resin; the mixture was stirred sufficiently to become homogenous and then dispersed on a InGaN chip with $380 \mathrm{~nm}$ emitting, and the package was solidified in oven at $120{ }^{\circ} \mathrm{C}$ for $40 \mathrm{~min}$.

\subsection{Synthesis}

2.3.1. General procedure for synthesis of compounds $2 \mathrm{a}-$ 2d. A solution of nopinone $(2 \mathrm{~mol})$ dissolved in ethylene glycol dimethyl ether was added to a suspension of $\mathrm{NaH}(6 \mathrm{~mol})$ in ethylene glycol dimethyl ether. ${ }^{43}$ The mixture was refluxed for $0.5 \mathrm{~h}$, whereupon compounds 1a-1d (3 mol) dissolved in ethylene glycol dimethyl ether was added to the reaction mixture under reflux. The reacted mixture was quenched by addition of EtOH (95\%) after $7 \mathrm{~h}$, and it was extracted with ethyl acetate, and the organic layers were washed with saturated brine to neutrality. After solvent evaporation, the yellow crude crystals were recrystallized from methanol to give $\mathbf{2 a - 2 d}$.

Compound 2a was a pale yellow solid, yield: $69.2 \%, \mathrm{mp}$ : 127.2-128.8 ${ }^{\circ} \mathrm{C} .{ }^{1} \mathrm{H}$ NMR $\left(400 \mathrm{MHz}, \mathrm{CDCl}_{3}\right) \delta: 15.61(\mathrm{~s}, 1 \mathrm{H}), 7.64-$ $7.57(\mathrm{~m}, 2 \mathrm{H}), 7.24(\mathrm{~d}, J=8.0 \mathrm{~Hz}, 2 \mathrm{H}), 2.70(\mathrm{dd}, J=3.1,1.2 \mathrm{~Hz}$, $2 \mathrm{H}), 2.61-2.49(\mathrm{~m}, 2 \mathrm{H}), 2.40(\mathrm{~s}, 3 \mathrm{H}), 2.28(\mathrm{tt}, J=6.0,3.1 \mathrm{~Hz}, 1 \mathrm{H})$, $1.45(\mathrm{~d}, J=9.5 \mathrm{~Hz}, 1 \mathrm{H}), 1.34(\mathrm{~s}, 3 \mathrm{H}), 0.96(\mathrm{~s}, 3 \mathrm{H}) .{ }^{13} \mathrm{C} \mathrm{NMR}(100$ $\mathrm{MHz}, \mathrm{CDCl}_{3}$ ) $\delta: 209.07,173.14,140.50,132.45,128.92,128.16$, 103.54, 54.72, 39.91, 39.50, 28.40, 27.80, 25.84, 21.53, 21.48. HRMS $(m / z):[\mathrm{M}+\mathrm{Na}]^{+}$calculated for $\mathrm{C}_{17} \mathrm{H}_{20} \mathrm{O}_{2}+\mathrm{Na}^{+}, 279.1361$; found, 279.1356 .

Compound 2 b was a yellow solid, yield: $65.7 \%$, mp: $113.2-$ 113.8 ${ }^{\circ} \mathrm{C} .{ }^{1} \mathrm{H}$ NMR (400 MHz, $\left.\mathrm{CDCl}_{3}\right) \delta: 15.79$ (s, 1H), 7.77-7.68 $(\mathrm{m}, 2 \mathrm{H}), 6.97-6.94(\mathrm{~m}, 2 \mathrm{H}), 3.86(\mathrm{~s}, 3 \mathrm{H}), 2.73(\mathrm{~d}, J=3.0 \mathrm{~Hz}, 2 \mathrm{H})$, 2.60-2.51 (m, 2H), $2.30(\mathrm{tt}, J=5.7,2.9 \mathrm{~Hz}, 1 \mathrm{H}), 1.46$ (d, $J=$ $9.2 \mathrm{~Hz}, 1 \mathrm{H}), 1.35$ (s, 3H), 0.96 (s, 3H). ${ }^{13} \mathrm{C} \mathrm{NMR}\left(100 \mathrm{MHz}, \mathrm{CDCl}_{3}\right)$ $\delta:$ 208.76, 172.94, 161.13, 130.05, 127.72, 113.57, 103.09, 55.35, 54.64, 39.99, 39.47, 28.66, 27.86, 25.82, 21.49. HRMS ( $\mathrm{m} / \mathrm{z}):[\mathrm{M}+$ $\mathrm{Na}]^{+}$calculated for $\mathrm{C}_{17} \mathrm{H}_{20} \mathrm{O}_{3}+\mathrm{Na}^{+}$, 295.1310; found, 295.1305.

Compound 2c was a pale yellow solid, yield: $45.8 \%, \mathrm{mp}$ : 114.1-114.5 ${ }^{\circ} \mathrm{C} .{ }^{1} \mathrm{H}$ NMR (400 MHz, $\left.\mathrm{CDCl}_{3}\right) \delta: 15.59$ (s, $\left.1 \mathrm{H}\right), 7.78-$ $7.65(\mathrm{~m}, 2 \mathrm{H}), 7.20-7.07(\mathrm{~m}, 2 \mathrm{H}), 2.68(\mathrm{t}, J=2.8 \mathrm{~Hz}, 2 \mathrm{H}), 2.66-$ $2.51(\mathrm{~m}, 2 \mathrm{H}), 2.30(\mathrm{tt}, J=6.0,3.1 \mathrm{~Hz}, 1 \mathrm{H}), 1.45(\mathrm{~d}, J=9.5 \mathrm{~Hz}$, 1H), 1.35 (s, 3H), 0.96 (s, 3H). ${ }^{13} \mathrm{C}$ NMR (100 MHz, $\left.\mathrm{CDCl}_{3}\right) \delta$ : 209.24, 171.81, 164.87, 162.38, 130.40, 115.34, 103.72, 54.71, $39.86,39.54,28.35,27.76,25.80,21.52$. HRMS $(m / z):[\mathrm{M}+\mathrm{Na}]^{+}$ calculated for $\mathrm{C}_{16} \mathrm{H}_{17} \mathrm{FO}_{2}+\mathrm{Na}^{+}$, 283.1111; found, 283.1105.

Compound 2d was a yellow solid, yield: $59.1 \%$, mp: $133.3-$ 133.9 ${ }^{\circ} \mathrm{C} .{ }^{1} \mathrm{H}$ NMR $\left(400 \mathrm{MHz}, \mathrm{CDCl}_{3}\right) \delta: 15.51(\mathrm{~s}, 1 \mathrm{H}), 7.60(\mathrm{~s}, 4 \mathrm{H})$, $2.69(\mathrm{t}, J=2.9 \mathrm{~Hz}, 2 \mathrm{H}), 2.63-2.53(\mathrm{~m}, 2 \mathrm{H}), 2.31(\mathrm{tt}, J=6.0,3.1 \mathrm{~Hz}$, $1 \mathrm{H}), 1.47$ (d, $J=9.6 \mathrm{~Hz}, 1 \mathrm{H}), 1.37$ (s, 3H), $0.98(\mathrm{~s}, 3 \mathrm{H}) .{ }^{13} \mathrm{C} \mathrm{NMR}$ $\left(100 \mathrm{MHz}, \mathrm{CDCl}_{3}\right) \delta: 209.42,171.40,134.07,131.50,129.79$, 124.66, 104.06, 54.77, 39.80, 39.56, 28.26, 27.73, 25.81, 21.55. HRMS $(m / z):[\mathrm{M}+\mathrm{Na}]^{+}$calculated for $\mathrm{C}_{16} \mathrm{H}_{17} \mathrm{BrO}_{2}+\mathrm{Na}^{+}$, 343.0310; found, 343.0304.

2.3.2. General procedure for synthesis of compounds 3a3d. $\mathrm{BF}_{3} \cdot\left(\mathrm{C}_{2} \mathrm{H}_{5}\right)_{2} \mathrm{O}(1.0 \mathrm{~mol})$ was added to a solution of compound $2 \mathbf{a}-2 \mathbf{d}(0.2 \mathrm{~mol})$ in dry dichloromethane, and the reaction mixture was stirred for $2 \mathrm{~h}$ at $45^{\circ} \mathrm{C}$. After removal of the solvent, the yellow crude crystals were recrystallized from methanol to give $\mathbf{3 a - 3 d}$.

Compound 3a was a pale yellow solid, yield: $92.6 \%, \mathrm{mp}$ : 139.3-139.6 ${ }^{\circ} \mathrm{C} .{ }^{1} \mathrm{H}$ NMR (400 MHz, $\left.\mathrm{CDCl}_{3}\right) \delta: 7.87-7.80(\mathrm{~m}, 2 \mathrm{H})$, $7.30(\mathrm{~d}, J=8.1 \mathrm{~Hz}, 2 \mathrm{H}), 2.94-2.83(\mathrm{~m}, 2 \mathrm{H}), 2.84-2.74(\mathrm{~m}, 1 \mathrm{H})$, 2.68 (dd, $J=11.0,5.7 \mathrm{~Hz}, 1 \mathrm{H}), 2.44$ (s, 3H), 1.49 (d, $J=10.1 \mathrm{~Hz}$, 1H), 1.42 (s, 3H), 1.26 (s, 1H), 0.97 (s, 3H). ${ }^{13} \mathrm{C}$ NMR (100 MHz, $\left.\mathrm{CDCl}_{3}\right) \delta: 201.83,179.42,144.19,130.60,129.62,129.33,104.19$, 51.25, 40.39, 39.79, 28.49, 28.41, 25.49, 21.72, 21.42. HRMS (m/ $z):[\mathrm{M}+\mathrm{Na}]^{+}$calculated for $\mathrm{C}_{17} \mathrm{H}_{19} \mathrm{BF}_{2} \mathrm{O}_{2}+\mathrm{Na}^{+}, 327.1344$; found, 327.1341 . 
Compound 3b was a yellow solid, yield: $89.3 \%$, mp: $147.7-$ $148.2{ }^{\circ} \mathrm{C} .{ }^{1} \mathrm{H}$ NMR $\left(400 \mathrm{MHz}, \mathrm{CDCl}_{3}\right) \delta: 8.04-7.96(\mathrm{~m}, 2 \mathrm{H}), 7.04-$ $6.92(\mathrm{~m}, 2 \mathrm{H}), 3.90(\mathrm{~s}, 3 \mathrm{H}), 2.89(\mathrm{dd}, J=14.6,3.0 \mathrm{~Hz}, 2 \mathrm{H}), 2.77(\mathrm{t}, J$ $=5.6 \mathrm{~Hz}, 1 \mathrm{H}), 2.73-2.60(\mathrm{~m}, 1 \mathrm{H}), 2.42(\mathrm{tt}, J=5.9,3.0 \mathrm{~Hz}, 1 \mathrm{H})$, $1.49(\mathrm{~d}, J=10.0 \mathrm{~Hz}, 1 \mathrm{H}), 1.42(\mathrm{~s}, 3 \mathrm{H}), 0.97$ (s, 3H). ${ }^{13} \mathrm{C}$ NMR $(100$ $\mathrm{MHz}, \mathrm{CDCl}_{3}$ ) $\delta: 200.80,178.45,163.72,132.26,125.68,114.05$, 103.54, 55.61, 51.17, 40.31, 39.90, 28.80, 28.57, 25.50, 21.39. HRMS $(\mathrm{m} / z):[\mathrm{M}+\mathrm{Na}]^{+}$calculated for $\mathrm{C}_{17} \mathrm{H}_{19} \mathrm{BF}_{2} \mathrm{O}_{3}+\mathrm{Na}^{+}$, 343.1293; found, 343.1291.

Compound 3c was a white solid, yield: $81.9 \%$, mp: $160.2-$ $160.8^{\circ} \mathrm{C} .{ }^{1} \mathrm{H}$ NMR $\left(400 \mathrm{MHz}, \mathrm{CDCl}_{3}\right) \delta: 8.04-7.92(\mathrm{~m}, 2 \mathrm{H}), 7.25-$ $7.12(\mathrm{~m}, 2 \mathrm{H}), 2.92-2.78(\mathrm{~m}, 3 \mathrm{H}), 2.70(\mathrm{dd}, J=10.5,5.8 \mathrm{~Hz}, 1 \mathrm{H})$, $2.43(\mathrm{tt}, J=5.9,3.0 \mathrm{~Hz}, 1 \mathrm{H}), 1.50$ (d, $J=10.2 \mathrm{~Hz}, 1 \mathrm{H}), 1.43(\mathrm{~s}$, $3 \mathrm{H}), 0.97$ (s, 3H). ${ }^{13} \mathrm{C} \mathrm{NMR}\left(100 \mathrm{MHz}, \mathrm{CDCl}_{3}\right) \delta: 202.81,177.96$, 166.66, 164.11, 132.13, 129.57, 115.94, 104.22, 51.38, 40.49, $39.75,28.39,25.47,21.42$. HRMS $(\mathrm{m} / \mathrm{z}):[\mathrm{M}+\mathrm{Na}]^{+}$calculated for $\mathrm{C}_{16} \mathrm{H}_{16} \mathrm{BF}_{3} \mathrm{O}_{2}+\mathrm{Na}^{+}$, 331.1093; found, 331.1091.

Compound 3d was a yellow solid, yield: $86.9 \%$, mp: $175.2-$ 175.7 ${ }^{\circ}$ C. ${ }^{1} \mathrm{H}$ NMR $\left(400 \mathrm{MHz}, \mathrm{CDCl}_{3}\right) \delta: 7.83-7.74(\mathrm{~m}, 2 \mathrm{H}), 7.69-$ $7.59(\mathrm{~m}, 2 \mathrm{H}) 2.91-2.75(\mathrm{~m}, 3 \mathrm{H}), 2.71(\mathrm{dd}, J=10.6,5.8 \mathrm{~Hz}, 1 \mathrm{H})$, $2.43(\mathrm{tt}, J=5.9,3.1 \mathrm{~Hz}, 1 \mathrm{H}), 1.49$ (d, $J=10.2 \mathrm{~Hz}, 1 \mathrm{H}), 1.43$ (s, $3 \mathrm{H}), 0.97$ (s, 3H). ${ }^{13} \mathrm{C} \mathrm{NMR}\left(100 \mathrm{MHz}, \mathrm{CDCl}_{3}\right) \delta: 203.26,178.01$, 132.21, 131.97, 130.81, 128.07, 104.57, 51.45, 40.56, 39.71, 28.41, 28.20, 25.50, 21.47. HRMS ( $\mathrm{m} / \mathrm{z})$ : $[\mathrm{M}+\mathrm{Na}]^{+}$calculated for $\mathrm{C}_{16} \mathrm{H}_{16} \mathrm{BBrF}_{2} \mathrm{O}_{2}+\mathrm{Na}^{+}$, 391.0293; found, 391.0290.

\section{Results and discussion}

\subsection{Synthesis}

The synthetic routines of four fluorescent compounds were shown in Scheme 1. The compounds $\mathbf{2 a - 2 d}$ were prepared from nopinone and compounds 1a-1d according to the Claisen condensation. Target compounds $\mathbf{3 a - 3 d}$ were then synthesized by reaction of compounds $2 \mathrm{a}-\mathbf{2 d}$ with $\mathrm{BF}_{3} \cdot\left(\mathrm{C}_{2} \mathrm{H}_{5}\right)_{2} \mathrm{O}$ with high yields. The chemical structures of the synthesized compounds were confirmed by ${ }^{1} \mathrm{H}$ NMR, ${ }^{13} \mathrm{C}$ NMR, and HRMS. Compounds were readily soluble in common organic solvents like THF, chloroform, ethyl acetate. The structure of $2 \mathbf{a}$ was also verified by X-ray crystallography (Fig. S1†). Suitable single crystals of 2a for X-ray structural analysis was obtained by slow evaporation of methanol solution at room temperature.

\subsection{Photophysical properties}

The photophysical properties of the resultant compounds 3a3d in neat film were investigated. The UV-vis absorption spectra of $\mathbf{3 a - 3 d}$ at room temperature are shown in Fig. 1. The compounds 3c, 3a, 3d, 3b, exhibited a strong absorption maximum in neat film at $366 \mathrm{~nm}$ to $368 \mathrm{~nm}, 374 \mathrm{~nm}$, and $388 \mathrm{~nm}$, respectively. The photoluminescence (PL) spectra of 3a-3d at room temperature are shown in Fig. 1. All obtained compounds showed obvious fluorescence emission (emission maxima $\lambda_{\mathrm{em}}=496 \mathrm{~nm}$ for $3 \mathbf{b} v s .480 \mathrm{~nm}$ for $3 \mathbf{d}, 463 \mathrm{~nm}$ for $3 \mathbf{a}$, and $441 \mathrm{~nm}$ for $3 \mathrm{c}$, Table 1), which can be ascribed to the different electron density dispersed on the molecules. Obviously, compound 3c showed bathochromic shift due to the presence of electron-donating methoxy, which enhanced
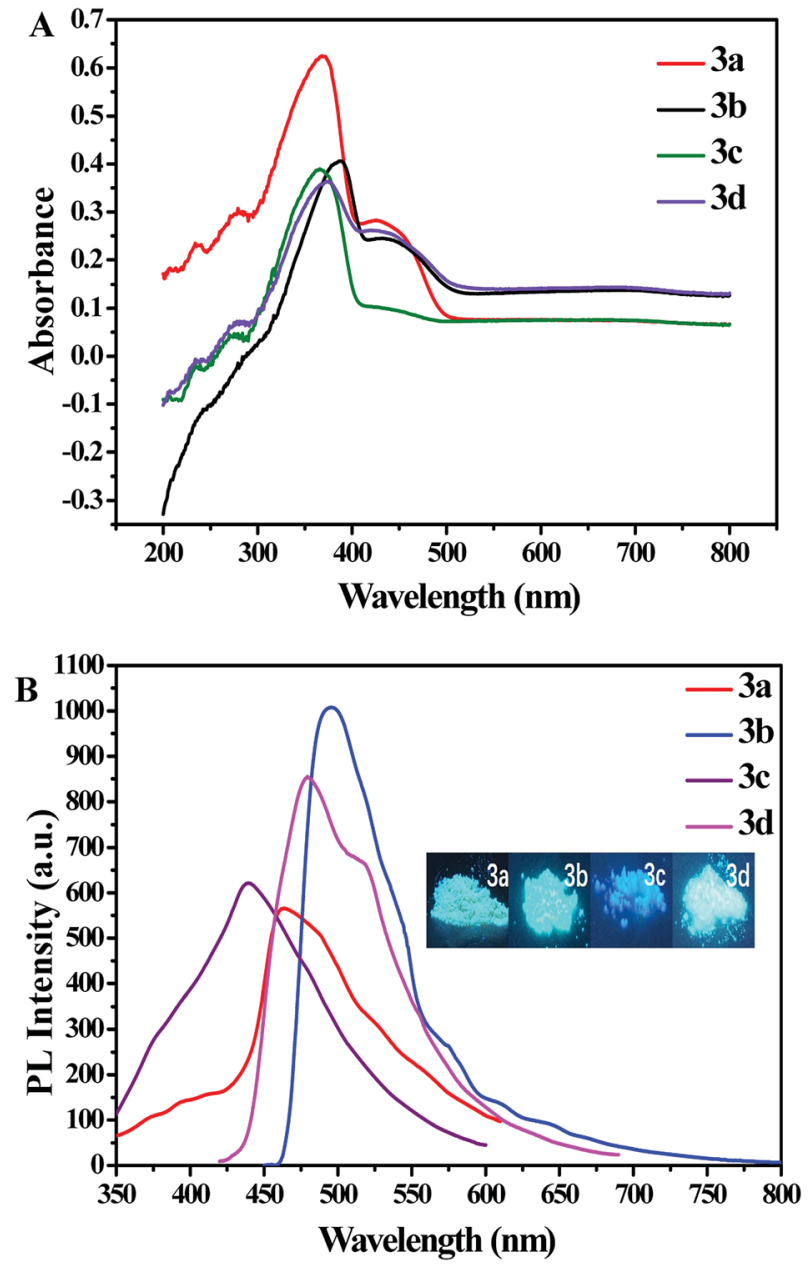

Fig. 1 (A) Absorbance spectra and (B) emission spectra of 3a-3d in neat film at room temperature. Inset: Photographs of $3 a-3 d$ under $365 \mathrm{~nm}$ UV light illumination.

intramolecular charge transfer (ICT) process between the electron-donating methoxy and the electron-accepting $\mathrm{BF}_{2} \mathrm{dbm}$ unit, and led to shift the $\lambda_{\max }$ to the long wavelength. The ICT process of these compounds were further studied in both experimental investigation (Fig. S2 $\dagger$ ) and theoretical calculation (Fig. 2).

The absolute photoluminescence quantum yields for compounds $\mathbf{3 a - 3 d}$ in solid state are summarized in Table 1 , and the values of compounds 3a-3d were $1.99 \%, 47.16 \%, 4.94 \%$ and $21.03 \%$, respectively. It was found that introduction of methyl, fluorine, bromine moiety did not make an obvious difference in

Table 1 Photophysical data of $3 a-3 d$

\begin{tabular}{lllllll}
\hline Compound & $\begin{array}{l}\lambda_{\mathrm{abs}} \\
(\mathrm{nm})\end{array}$ & $\begin{array}{l}\lambda_{\mathrm{em}} \\
(\mathrm{nm})\end{array}$ & \multicolumn{1}{c}{$\Phi_{\mathrm{F}}{ }^{a}$} & $\tau_{\mathrm{F}}(\mathrm{ns})$ & $\begin{array}{l}K_{\mathrm{f}}^{b} \\
\left(10^{9} \mathrm{~s}^{-1}\right)\end{array}$ & $\begin{array}{l}K_{\mathrm{nr}}{ }^{c} \\
\left(10^{9} \mathrm{~s}^{-1}\right)\end{array}$ \\
\hline 3a & 368 & 463 & $1.99 \%$ & 1.52 & 0.01 & 0.64 \\
$3 \mathbf{b}$ & 388 & 496 & $37.16 \%$ & 4.52 & 0.08 & 0.14 \\
3c & 366 & 441 & $4.94 \%$ & 1.10 & 0.04 & 0.86 \\
3b & 374 & 480 & $12.03 \%$ & 2.15 & 0.06 & 0.41
\end{tabular}

${ }^{a} \Phi_{\mathrm{F}}$ is the absolute photoluminescence quantum yields. ${ }^{b}$ Radiative rate constant $\left(k_{\mathrm{f}}=\Phi_{\mathrm{f}} / \tau_{\mathrm{f}}\right) .{ }^{c}$ Non radiative rate constant $\left(k_{\mathrm{nr}}=\left(1-\Phi_{\mathrm{f}}\right) / \tau_{\mathrm{f}}\right)$. 
$3 a$

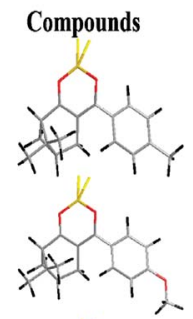

$3 c$

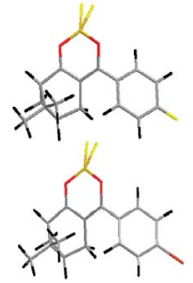

$-5.94$
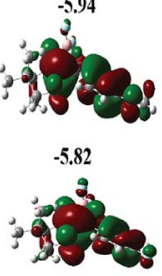

$-610$

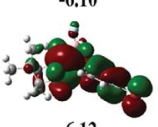

$-6.12$

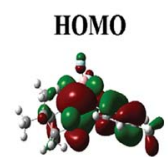

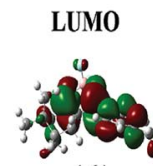

$-1.64$

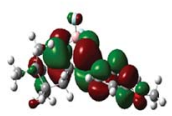

$-1.70$

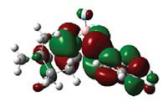

$-1.77$

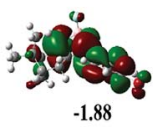

$\Delta \mathrm{E}_{\mathrm{g}}$

4.30

4.12

4.24
Fig. 2 HOMO and LUMO diagrams of $3 a-3 d$

terms of the fluorescence lifetime $\left(3 \mathrm{a}, \tau_{\mathrm{f}}=1.52 \mathrm{~ns} ; 3 \mathbf{c}, \tau_{\mathrm{f}}=1.10\right.$ $\left.\mathrm{ns} ; 3 \mathbf{d}, \tau_{\mathrm{f}}=2.15 \mathrm{~ns}\right)$. However, compared with other compounds, the fluorescence lifetime of $\mathbf{3 b}$ substituted with methoxy has increased by 2 times $\left(3 \mathbf{b}, \tau_{\mathrm{f}}=4.52 \mathrm{~ns}\right)$. Based on fluorescence lifetimes of these compounds, radiative and nonradiative rate constants $\left(k_{\mathrm{f}}\right.$ and $\left.k_{\mathrm{nr}}\right)$ were respectively estimated. ${ }^{44,45}$ As shown in Table 1, methoxy group increased the $k_{\mathrm{f}}$ (the radiative rate constant) and decreased the $k_{\mathrm{nr}}$ (the nonradiative rate constant) of $\mathrm{BF}_{2}$ complexes. Thus, the introduction of different substituent functional groups can significantly affect the photoluminescence properties of $\mathrm{BF}_{2}$ complexes.

\subsection{Electrochemical properties and theoretical calculations}

The electrochemical properties of $\mathbf{3 a - 3 \mathbf { d }}$ were examined using cyclic voltammetry. The cyclic voltammograms of the $\mathbf{3 a - 3 \mathbf { d }}$ are shown in Fig. S2, $\dagger$ the onset oxidation potentials $\left(E_{\text {OX }}\right)$ were found to be 1.30, 1.26, 1.34 and $1.35 \mathrm{~V}$ for compounds $3 \mathrm{a}-3 \mathrm{~d}$. According to the equation $\left[\mathrm{HOMO}=-\left(4.40+E_{\mathrm{OX}}\right)\right]$, the HOMO energy levels were calculated. The lowest unoccupied molecular orbital energy levels $\left(E_{\mathrm{LUMO}}\right)$ is calculated based on the equation of $E_{\mathrm{LUMO}}=E_{\mathrm{HOMO}}+E_{\mathrm{g}}$, in which energy band gap $\left(E_{\mathrm{g}}=4.1 \mathrm{eV}\right.$ for $3 \mathbf{a}, 3.89 \mathrm{eV}$ for $3 \mathbf{b}, 4.11 \mathrm{eV}$ for $3 \mathbf{c}$ and $4.05 \mathrm{eV}$ for $\mathbf{3 d}$, respectively) were estimated from the UV-vis absorption. HOMO-LUMO gap is usually used to characterize the ICT occurred in chromophore molecules. The HOMO, LUMO and $E_{\mathrm{g}}$ are listed in Table 2. The CV curves of these compounds remained unchanged under multiple successive scans,

Table 2 Electrochemical properties and thermostability of 3a-3d

\begin{tabular}{|c|c|c|c|c|c|c|c|}
\hline \multirow[b]{2}{*}{ Compounds } & \multicolumn{2}{|c|}{ HOMO (eV) } & \multicolumn{2}{|c|}{ LUMO (eV) } & \multicolumn{2}{|l|}{$E_{\mathrm{g}}(\mathrm{eV})$} & \multirow[b]{2}{*}{$T_{\mathrm{d}}\left({ }^{\circ} \mathrm{C}\right)$} \\
\hline & Exptl $^{a}$ & Calc & $\operatorname{Exptl}^{a}$ & Calc & $\operatorname{Exptl}^{b}$ & Calc & \\
\hline $3 \mathbf{a}$ & 5.70 & -5.94 & -1.60 & -1.64 & 4.10 & 4.30 & 252.3 \\
\hline $3 \mathbf{b}$ & 5.66 & -5.82 & -1.77 & -1.70 & 3.89 & 4.12 & 296.6 \\
\hline $3 \mathbf{c}$ & 5.74 & -6.10 & -1.63 & -1.77 & 4.11 & 4.33 & 232.8 \\
\hline 3d & 5.75 & -6.12 & -1.70 & -1.88 & 4.05 & 4.24 & 285.4 \\
\hline
\end{tabular}

demonstrating their good stability against electrochemical oxidation.

To further investigate the relationship between the emission and the structure property of the four compounds at the molecular level, the geometrical structures of compounds 3a-3d were analyzed employing DFT calculations. The electron density distributions of target compounds are illustrated in Fig. 2. The electron clouds of the HOMOs and LOMOs for $\mathbf{3 a}, \mathbf{3 c}$, $\mathbf{3 d}$ were mainly distributed over whole molecule. The electron clouds of the HOMOs in $\mathbf{3 b}$ were mainly distributed over the whole molecule, and the electron clouds of the LUMOs were mostly distributed over $\mathrm{BF}_{2} \mathrm{dbm}$ unit due to electron withdrawing ability of the $\mathrm{BF}_{2} \mathrm{dbm}$ unit. These results further prove that the ICT process occurs from the donor to the acceptor moiety. The corresponded data are summarized in Table 2. According to the calculations, introduction of methoxy may reduce the HOMOLUMO energy gap ( $4.12 \mathrm{eV}$ for $\mathbf{3 b}, 4.24 \mathrm{eV}$ for $\mathbf{3 d}, 4.3 \mathrm{eV}$ for $3 \mathbf{a}$ and $4.33 \mathrm{eV}$ for $3 \mathbf{c}$, respectively) which is consistent with the results of cyclic voltammetry. The HOMO and LUMO gap of compound $\mathbf{3 b}$ is lower than that of $\mathbf{3 a}, \mathbf{3} \mathbf{c}, \mathbf{3 d}$, which could lead to a red-shift in the absorption and fluorescence spectra. The conclusion is coincident with the experimental results.

\subsection{Thermal properties}

The thermal stabilities of four new compounds were evaluated by thermogravimetric analysis (TGA) under a stream of $\mathrm{N}_{2}$ with a scanning rate of $10^{\circ} \mathrm{C} \mathrm{min}^{-1}$. Their TGA curves are shown in Fig. $\mathrm{S} 3 \uparrow$ and their degradation temperatures $\left(T_{\mathrm{d}}\right)$ for $5 \%$ weight loss are listed in Table 2. The degradation temperatures $T_{\mathrm{d}}$ for compounds 3a-3d were 252.3, 296.6, 232.8 and $285.4{ }^{\circ} \mathrm{C}$, respectively. The data demonstrate that the resulting compounds can possess good thermal properties, which is desirable for the application in electroluminescent materials.

\subsection{Aggregation-induced emission performances}

The PL emission spectra of resultant compounds 3a-3d in DMF/ water mixtures with different water fractions $\left(f_{\mathrm{w}}: 0-90 \%\right)$ in Fig. S4-S6, $\dagger$ Fig. 3 reveals that the PL intensity of $\mathbf{3 b}$ is slightly weakened upon addition of a small amount of water $\left(f_{\mathrm{w}} \leq 20 \%\right)$ and the dramatic enhancement of luminescence is observed for the water fraction $\left(f_{\mathrm{w}}\right)$ of $30 \%$. Similar observation is seen for $\mathbf{3 c}$, 3a and 3d. All compounds showed higher emission intensity when water fractions $\left(f_{\mathrm{w}}\right)$ was $90 \%$.

According to the Fig. S7, $\uparrow$ the emission of $\mathbf{3 b}$ is weaker in pure DMF solution owing to the twisted intramolecular charger transfer (TICT) emission. The emission spectra remained almost unchanged when the water volume fraction was gradually increased from $0 \%$ to $20 \%$. When the water content was further increased from $30 \%$ to $90 \%$, the fluorescence intensity was swiftly enhanced, which attributed to the restriction of intramolecular rotation (RIR) ${ }^{46-48}$ According to the Fig. $S 7, \dagger$ the emission of $\mathbf{3 b}$ in the water fraction $\left(f_{\mathrm{w}}\right)$ of $60 \%$ is weaker than that of $50 \%$, which is probably due to the difference in aggregate morphology ${ }^{49,50}$ It is obvious that the poor solvent water could induce the fluorescence intensity increase, demonstrating the AIE characteristics of the four compounds. 


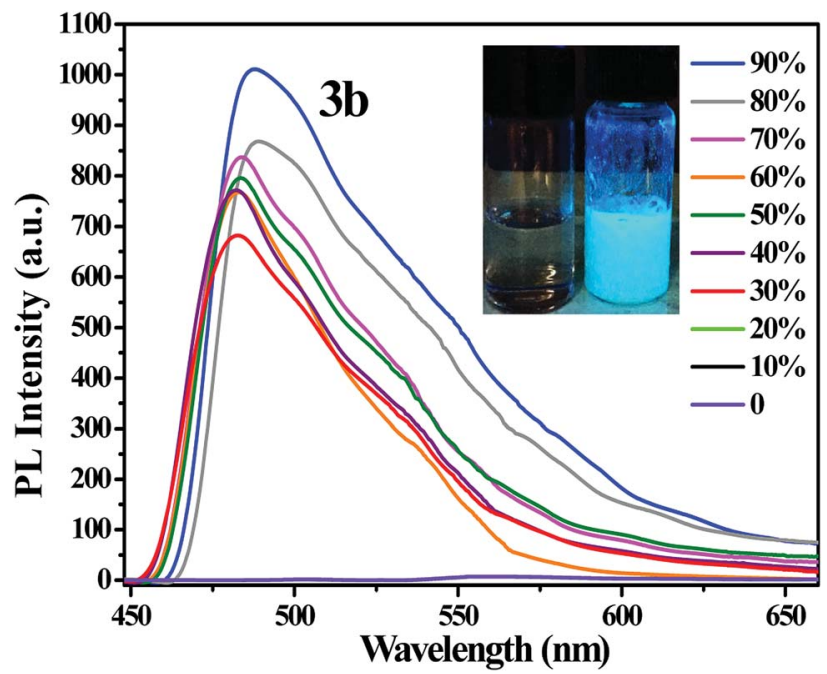

Fig. $3 \mathrm{PL}$ spectra of $3 b$ in DMF/water mixtures with different water fractions. Inset: Photographs of $3 b$ in DMF/water mixtures $\left(f_{w}=0 \%\right.$ and $90 \%$ ), taken under $365 \mathrm{~nm}$ UV light illumination.

\subsection{Electroluminescent devices}

Owing to relatively high absolute fluorescence quantum yields of $\mathbf{3 b}$ and $\mathbf{3 d}$, EL devices based on $\mathbf{3 b}$ and $\mathbf{3 d}$ were fabricated. As shown in Fig. 4 and Fig. S8, $\uparrow$ both of the devices I and II display blueish-green light (peak at $499.2 \mathrm{~nm}$ and peak at $500.4 \mathrm{~nm}$, respectively), the Commission Internationale de L'Eclairage (CIE) coordinates of devices I and devices II are located at $(0.2774,0.4531)$ and $(0.3084,0.4800)$ respectively, which are close to their solid PL spectra.

As showed in Fig. 5 and Table 3, the EL performances of the luminescent materials substituted with methoxy was better than the luminescent materials substituted with bromine, which is identical to the order of photophysical properties in the solid state. For the device of I, a luminous efficacy $\left(\eta_{\mathrm{p}}\right)$ of $7.09 \mathrm{~lm} \mathrm{~W} \mathrm{~W}^{-1}$, a color rendering index $\left(R_{\mathrm{a}}\right)$ of $\mathbf{5 4 . 4}$ and a correlated color temperature $\left(T_{\mathrm{C}}\right)$ of $7028 \mathrm{~K}$ at a current density of 9.9 $\mathrm{mA}$ were achieved. Therefore, the nopinone derivative containing difluoroboron is still one effective strategy for new EL materials.

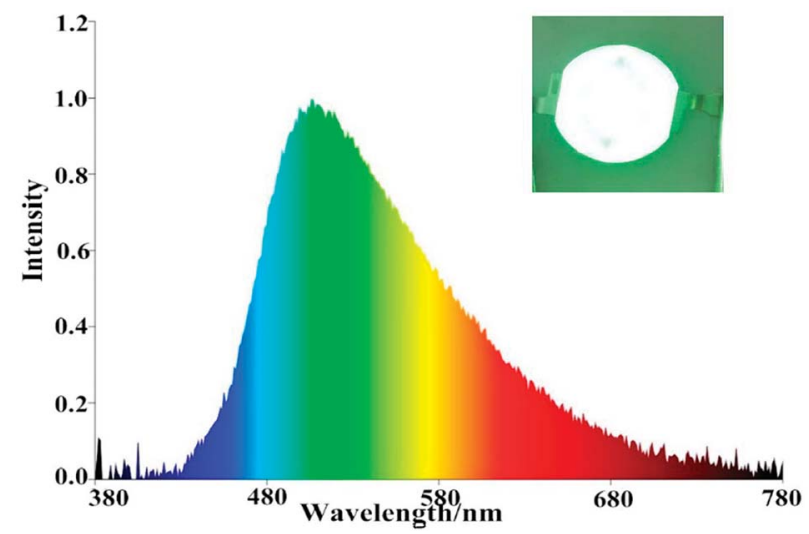

Fig. 4 EL spectra of device I (3b). Inset: Photographs of device I (3b) at a current density of $9.9 \mathrm{~mA}$.

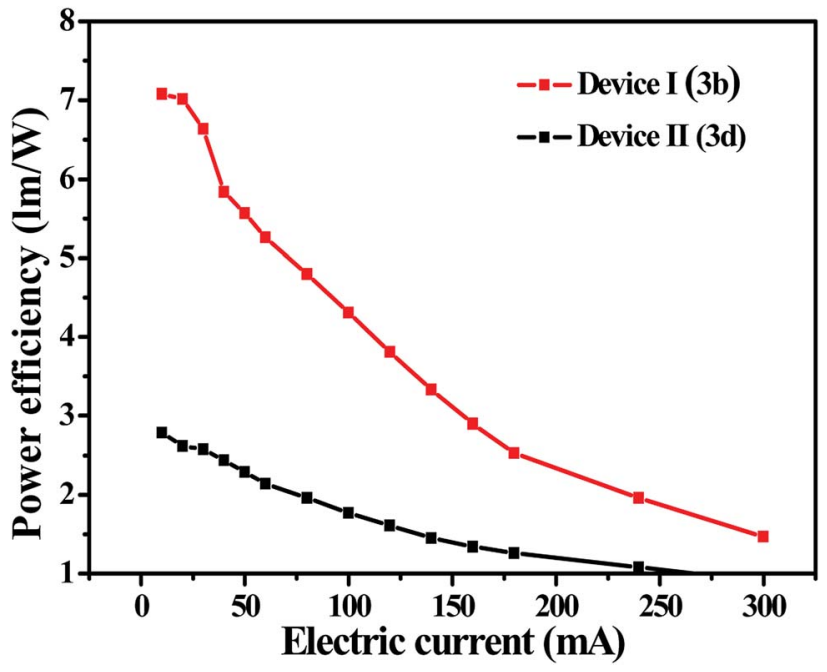

Fig. 5 The electric current-power efficiency curves of the device I (3b) and II (3d).

Table 3 Electroluminescence properties of device I (3b) and II (3d)

\begin{tabular}{lllllll}
\hline Device & $V_{\mathrm{F}}(\mathrm{V})$ & $\mathrm{EL}(\mathrm{nm})$ & $\eta_{\mathrm{p}}\left(\mathrm{lm} \mathrm{W}^{-1}\right)$ & $T_{\mathrm{C}}(\mathrm{K})$ & $\mathrm{CIE}(x, y)$ & $R_{\mathrm{a}}$ \\
\hline I & 3.075 & 499.2 & 7.08 & 7028 & $(0.2774,0.4531)$ & 54.4 \\
II & 3.06 & 500.4 & 2.79 & 6087 & $(0.3084,0.4800)$ & 55.4
\end{tabular}

\section{Conclusions}

In summary, four novel nopinone derivative containing difluoroboron $\beta$-diketonate groups $\mathbf{3 a - 3 d}$ were synthesized with a simple method. The photophysical experiments demonstrated that the maximum absorption wavelengths of new compounds were in the range of 360-390 $\mathrm{nm}$ and the maximum fluorescence wavelengths of new compounds were in the range of 440-500 nm. These compounds also exhibited emission enhancement in their aggregate state. Besides, four target compounds 3a-3d exhibited high thermal stabilities, which is necessary for fabricating long lifetime devices. Theoretical calculations (DFT) were performed to provide further insights into our experimental results. Furthermore, devices I and II were fabricated which displayed blueish-green EL emission (peak at $499.2 \mathrm{~nm}$ and $500.4 \mathrm{~nm}$, respectively). Among the two devices, the device of I exhibited the highest device performance with a luminous efficacy $\left(\eta_{\mathrm{p}}\right)$ of 7.09 $\operatorname{lm} \mathrm{W}^{-1}$, a color rendering index $\left(R_{\mathrm{a}}\right)$ of 54.4 and a correlated color temperature $\left(T_{\mathrm{C}}\right)$ of $7028 \mathrm{~K}$, which provide guidance for the design and synthesis of new efficient EL materials in the future.

\section{Conflicts of interest}

There are no conflicts to declare.

\section{Acknowledgements}

The research was supported by the National Natural Science Foundation of China (No. 31470592), the Natural Science 
Foundation of Jiangsu Province (Grants No. BK20151513), Jiangsu Provincial Key Lab for the Chemistry and Utilization of Agro-Forest Biomass, and Priority Academic Program Development of Jiangsu Higher Education Institutions, China.

\section{References}

1 A. Kamkaew, S. H. Lim and H. B. Lee, Chem. Soc. Rev., 2013, 42, 77-88.

2 N. Boens, V. Leen and W. Dehaen, Chem. Soc. Rev., 2012, 41, 1130-1172.

3 F. Cardona, J. Rocha and A. M. S Silva, Dyes Pigm., 2014, 111, 16-20.

4 S. Guieu, F. Cardona and J. Rocha, New J. Chem., 2014, 38, 5411-5414.

5 S. Xu, R. E. Evans and T. Liu, Inorg. Chem., 2013, 52, 35973610.

6 P. Galer, R. C. Korošec and M. Vidmar, J. Am. Chem. Soc., 2014, 136, 7383-7394.

7 S. Guieu, J. Pinto and V. L. M. Silva, Eur. J. Org. Chem., 2015, 3423-3426.

8 H. Zhang, C. Liu and J. Xiu, Dyes Pigm., 2017, 136, 798-806.

9 C. T. Poon, W. H. Lam and H. L. Wong, J. Am. Chem. Soc., 2010, 132, 13992-13993.

10 A. D'Aléo, D. Gachet and V. Heresanu, Chem.-Eur. J, 2012, 18, 12764-12772.

11 H. X. Zhang, J. B. Chen and X. F. Guo, Anal. Chem., 2014, 86, 3115-3121.

12 W. Liu, F. Li and X. Chen, J. Am. Chem. Soc., 2014, 136, 44684471.

13 Y. Zhou, Y. Z. Chen and J. H. Cao, Dyes Pigm., 2015, 112, 162169.

14 S. Chambon, A. D'Aléo and C. Baffert, Chem. Commun., 2013, 49, 3555-3557.

15 G. Q. Zhang and J. B. Chen, J. Am. Chem. Soc., 2007, 129, 8942-8943.

16 G. Zhang, J. Lu and M. Sabat, J. Am. Chem. Soc., 2010, 132, 2160-2162.

17 M. Y. Liu, Z. Lu and J. B. Sun, Dyes Pigm., 2016, 128, 271-278. 18 I. García-Moreno, F. Amat-Guerri and M. Liras, Adv. Funct. Mater., 2010, 17, 3088-3098.

19 H. Maeda, T. Shirai and S. Uemura, Chem. Commun., 2013, 49, 5310-5312.

20 R. Yamaka, T. Sakurai and W. Matsuda, Chem.- Eur. J, 2016, 22, 626-638.

21 X. Sun, X. Zhang and X. Li, J. Mater. Chem., 2012, 22, 1733217339.
22 Q. Chong, M. Y. Liu and G. H. Hong, Org. Biomol. Chem., 2015, 13, 2986-2991.

23 C. A. Derosa and Z. Fan, Macromolecules, 2015, 48, 29672977.

24 J. Samonina-Kosicka, C. A. Derosa and W. A. Morris, Macromolecules, 2014, 47, 3736-3746.

25 J. D. Luo, Z. L. Xie and B. Z. Tang, Chem. Commun., 2001, 18, 1740-1741.

26 B. Xu, J. He and Y. Mu, Chem. Sci., 2015, 6, 3236-3241.

27 M. Luo, X. Zhou and Z. Chi, Dyes Pigm., 2014, 101, 74-84.

28 Z. Zhao, W. Y. L. Lam and B. Z. Tang, J. Mater. Chem., 2012, 22, 23726-23740.

29 J. Yang, N. Sun and J. Huang, J. Mater. Chem. C, 2015, 3, 2624-2631.

30 L. Chen, Y. Jiang and H. Nie, Adv. Funct. Mater., 2014, 24, 3621-3630.

31 J. Mei, J. Wang and J. Z. Sun, Chem. Sci., 2012, 3, 549-558.

32 S. Choi, J. Bouffard and Y. Kim, Chem. Sci., 2013, 5, 751-755.

33 R. Hu, C. F. Gómez-Durán and J. W. Lam, Chem. Commun., 2012, 48, 10099-10101.

34 C. Liu, W. He and G. Shi, Dyes Pigm., 2015, 112, 154-161.

35 X. Zhang, Z. Chi and B. Xu, J. Mater. Chem., 2012, 22, 1850518513.

36 Y. Guo, X. Feng and T. Han, J. Am. Chem. Soc., 2014, 136, 15485-15488.

37 S. Kaur, A. Gupta and V. Bhalla, J. Mater. Chem. C, 2014, 2, 7356-7363.

38 Z. Zheng, Z. Yu and M. Yang, J. Org. Chem., 2013, 78, 32223234.

39 S. Liao, S. Shang and M. Shen, Bioorg. Med. Chem. Lett., 2016, 26, 1512-1515.

40 Z. Szakonyi, T. Gonda and F. Fülöp, Tetrahedron: Asymmetry, 2014, 25, 1138-1145.

41 J. Ścianowski, J. Szumera and P. Kleman, Tetrahedron: Asymmetry, 2016, 27, 238-245.

42 J. Yang, H. Xu and X. Xu, Dyes Pigm., 2016, 128, 75-85.

43 T. Wu and X. You, J. Phys. Chem. A, 2012, 116, 8959-8964.

44 M. Lin, Y. Yu and L. Li, Org. Electron., 2018, 57, 123-132.

45 H. Liu, Z. Lu and B. Tang, Dyes Pigm., 2018, 149, 284-289.

46 G. W. Kim, D. R. Yang and C. K. Yong, Dyes Pigm., 2016, 136, 8-16.

47 H. Dong, M. Luo and S. Wang, Dyes Pigm., 2016, 139, 118128.

48 C. Li, W. Yang and W. Zhou, New J. Chem., 2016, 40, 88378845.

49 F. Zhang, Y. Guan and S. Wang, Dyes Pigm., 2016, 130, 1-8. 50 W. Li, T. Xu and G. Chen, Dyes Pigm., 2018, 149, 266-272. 